\title{
Impact of E-Government in Reducing Administrative and Financial Corruption in Jordan - Ministry of Finance (Study Case)
}

\author{
Hisham Ali Shatnawi \\ Faculty of Business Administration, Ajloun University, Ajloun, Jordan \\ Email address: \\ Shatnawi_hisham@yahoo.com
}

\section{To cite this article:}

Hisham Ali Shatnawi. Impact of E-Government in Reducing Administrative and Financial Corruption in Jordan - Ministry of Finance (Study Case). American Journal of Operations Management and Information Systems. Vol. 4, No. 4, 2019, pp. 124-131.

doi: 10.11648/j.ajomis.20190404.12

Received: January 25, 2019; Accepted: May 31, 2019; Published: January 6, 2020

\begin{abstract}
The aim of the study is to identify the impact of e-government in reducing administrative and financial corruption in Jordan. The Ministry of Finance was chosen as one of the first ministries to implement e-government procedures. The researcher will address the role of e-government in reducing the manifestations of administrative and financial corruption and highlighting the concept of administrative and financial corruption and the impact on the spread of these diseases from the low efficiency of public investment and weaken the quality of work and infrastructure as well as to identify the views of the study sample regarding the role of e-government in combating this case. The researcher adopted the descriptive analytical method (a case study) to conduct a survey by analyzing the results of a questionnaire to survey the reality of e-government in combating financial and administrative corruption. The information was collected from theoretical sources and electronic sites as well as previous studies interested in this regard. 176) employees and (27) question. The responses of the sample of the study were analyzed by using the statistical package for social studies. The study concluded that the hypotheses proved that there were no statistically significant differences between the sex variables. The intention of the study recommended to take advantage of technology and technical information and devote its use as an integral part of the daily dealings of citizens, institutions and government bodies. The results of the study showed that the lack of citizen's conviction of the application of e-government and its procedures is the most important reasons that prevented its application. Moreover, the most important causes of administrative and financial corruption in the Jordanian society is due to first economic reasons, social in the second place and legally as the third place. The study presented a number of recommendations and proposals.
\end{abstract}

Keywords: E-Government, Administrative Corruption, Financial Corruption

\section{Introduction}

The tremendous technological development that the world is witnessing in the various aspects of life have forced governments to keep pace with this modernization and progress for their citizens. All services are easily and without complication through various electronic services which saves money and time and helps maintain public money from theft or loss

Through the use of information systems control and electronic programs that keep information and works to secure the rights of citizens

This study will explain the role of e-government in achieving that end.

\subsection{Previous Studies}

Mohammed Saleh Al-Obeidi [1] entitled: E-government after the US occupation and resistance to financial corruption. The study highlighted the manifestations of financial corruption and its causes, which were reflected in the political corruption that spread in Iraq after the withdrawal of US forces from Iraq. The study concluded that the absence of democracy and the deterioration of the political situation are the main causes of financial corruption and concluded with a set of recommendations, such as establishing democratic rules and allowing the people to 
participate in honest decisions and activating the role of electronic government and institutions of supervision, accountability, integrity and transparency.

The study of Safa Mouloud Rebhi [2] entitled: The role of e-government in improving public services and fighting financial corruption - Algeria. The study considered financial corruption a negative phenomenon suffered by the human societies throughout the ages and that the Algerian state sought to reduce them through electronic government and the mechanisms and means of use. The study concluded that the manifestations of corruption vary with the diversity of human activity, and that the face of this danger is combined with the efforts of the authorities and official and non-official institutions in society and the enactment of laws and penalties deterrent to this regard.

Hassan Ghoneim study [3] entitled: The impact of electronic government on monitoring the financial irregularities of the Jordanian ministries and means of combating financial corruption therein. The study highlighted the negative gaps in the application of e-government procedures and showed weaknesses in them. The study concluded that the absence of electronic control over the administrative and accounting procedures and the accounting information systems used for financial monitoring need to review the distribution of powers granted to financial observers and increase their effectiveness to include administrative staff and not limited to managers only.

\subsection{Concept of E-Government}

The official appearance of the e-Government concept was at an IT conference in Naples, Italy, in March [4], It was pointed out that e-government is a group of information and communication technology such as networks linking external communications with Internet sites by government agencies and the citizens themselves. Soka and Ben Mohamed El Hassan defined it as: is to use the results of technology in improving the performance of government agencies, increase efficiency, enhance its effectiveness And achieve the desired objectives [5-6].

The idea of e-government is based on four pillars:

1. To collect all informations, interactive activities and services in one place which is the government's official website.

2. To Achieve a state of permanent contact with the public, while ensuring all the educational and service needs of the citizens.

3. To achieve speed and effectiveness in the connection, coordination, performance and achievement between government departments and each and every one of them.

4. Achieve savings in spending on all elements including better benefits from government activities with commercial content.

The e-government has some advantages that serve as criteria for measuring the efficiency and quality of the administrative work of the government, which includes Razi [7]:
1. Accelerating completion: work to complete transactions without waiting in the waiting lines.

2. Increased proficiency: electronic services are characterized by speed and proficiency.

3. Reduce costs: Reduce service costs due to e-business.

4. Simplifying procedures: reducing red tape, employee review and bureaucratic work.

5. To achieve administrative transparency: to remove the parties to deal with each other, which removes the possibility of bribery, manipulation and abuse.

Requirements for achieving electronic government.

E-government is a way to build a strong economy, a strong society and contribute to solving many of the economic and social problems, especially administrative and financial corruption.

E-government works to save time, effort and expenses and therefore require specific requirements, the most important of which is the following Alqarwa [8]:

1. Infrastructure: a modern telecommunications network capable of securing and delivering information.

2. Availability of electronic means: Machines and electronic accessories, considering that the prices are accessible to all.

3. Provide Internet Service Providers ISPs: provide Internet access for high efficiency and reasonable prices for all citizens.

4. A comprehensive marketing and advertising plan: to highlight e-government optimizers and the participation and interaction of citizens with them.

5. The existence of legislations and legal texts: to legalize the electronic government and credibility in dealing.

6. Providing security and electronic confidentiality: This is to protect national and personal information and to safeguard the electronic archive from any penetration.

7. Training and cognitive capacity building: Training of employees and citizens how to use computers and egovernment programs.

The motives of e-government.

Most countries seek to achieve and promote economic development and helped the adoption of modern electronic governments to create the appropriate environment for this purpose and from the events that motive towards egovernment Alqarwah [9] was:

1. The emergence of electronic commerce and the required business to connect with government institutions and citizens.

2. The spread of privatization projects and their application requires communication between the public and private sectors and other institutions.

3. Wide success of Internet companies and business models.

4. The contribution of IT in reducing costs to the lowest levels.

The reality of e-government in Jordan through global indicators.

The United Nations Report on Arab e-Government 2012 was published entitled Electronic Governments for the People 
it focused on the role of e-government in sustainable development and the 2014 report entitled e-government for the increasing feature [10-11]. It focused on confronting egovernment the multiple and complex challenges faced by societies, and the report of 2016 entitled e-government to support sustainable development in which the ranking of Arab countries [12]. The following table 1 shows the ranking of these countries and the ranking of Jordan in the eighth rank:

Table 1. Ranking of countries according to the United Nations E-Government Report [13-15].

\begin{tabular}{|c|c|c|c|c|c|c|c|c|c|c|c|}
\hline Country & & UAE & Bahrain & KSA & Qatar & Kuwait & Oman & Lebanon & Jordan & Tunisia & Egypt \\
\hline Index result 2012 & & 0.7344 & 0.6946 & 0.6658 & 0.6405 & 0.596 & 0.5944 & 0.5139 & 0.4884 & 0.4833 & 0.4611 \\
\hline Ranking 2012 & Arab & 1 & 2 & 3 & 4 & 5 & 6 & 7 & 8 & 9 & 10 \\
\hline Index result 2014 & & 0.7136 & 0.8089 & 0.69 & 0.6362 & 0.6268 & 0.6273 & 0.4982 & 0.5167 & 0.539 & 0.5129 \\
\hline \multirow{2}{*}{ ranking 2014} & Arab & 2 & 1 & 3 & 4 & 6 & 5 & 10 & 8 & 7 & 9 \\
\hline & international & 32 & 18 & 36 & 44 & 49 & 48 & 89 & 79 & 75 & 80 \\
\hline Index result 2016 & & 0.7515 & 0.7734 & 0.6822 & 0.6699 & 0.708 & 0.5962 & 0.5646 & 0.5123 & 0.5682 & 0.4068 \\
\hline \multirow{2}{*}{ ranking 2016} & Arab & 2 & 1 & 4 & 5 & 3 & 6 & 8 & 10 & 7 & 11 \\
\hline & international & 29 & 24 & 44 & 48 & 40 & 66 & 73 & 91 & 72 & 107 \\
\hline
\end{tabular}

Table 1. Continued.

\begin{tabular}{|c|c|c|c|c|c|c|c|c|c|c|c|}
\hline Country & & Morocco & Syria & Algeria & Iraq & Sudan & Yemen & Comoros & Djibouti & Mauritania & Somalia \\
\hline Index result 2012 & & 0.4209 & 0.3705 & 0.3608 & 0.3409 & 0.261 & 0.2472 & 0.2358 & 0.2228 & 0.1996 & 0.064 \\
\hline \multirow{2}{*}{ Ranking 2012} & Arab & 11 & 12 & 13 & 14 & 15 & 16 & 17 & 18 & 19 & 20 \\
\hline & international & 120 & 128 & 132 & 137 & 165 & 167 & 171 & 176 & 181 & 190 \\
\hline Index result 2014 & & 0.506 & 0.3134 & 0.3106 & 0.3141 & 0.2606 & 0.272 & 0.1808 & 0.1456 & 0.1893 & 0.0139 \\
\hline \multirow{2}{*}{ ranking 2014} & Arab & 11 & 15 & 14 & 12 & 16 & 17 & 18 & 19 & 17 & 20 \\
\hline & international & 82 & 135 & 136 & 134 & 154 & 150 & 177 & 184 & 174 & 193 \\
\hline \multicolumn{2}{|l|}{ Index result 2016} & 0.5186 & 0.3404 & 0.2999 & 0.3334 & 0.2539 & 0.2248 & 0.2155 & 0.1337 & 0.1734 & 0.027 \\
\hline ranking 2016 & Arab & 9 & 12 & 14 & 13 & 15 & 16 & 17 & 19 & 18 & 20 \\
\hline
\end{tabular}

The source is prepared by researchers based on the United Nations' e-government reports [13-15].

The report [16] is the latest UN report on e-government. The report recognizes that for the first time, UN member states have 193 local Web sites, And whose degree of development varies from low to good

Like the countries of the world, the Arab countries are now interested in technological progress and its uses in various aspects, where without exception these countries were present in the reports of the United Nations, However, this presence is uneven. We note from the report the extent of the gap between the Kingdom of Bahrain, which ranked first in the Arab and ranked 24 worldwide and Somalia is the last Arab and internationally occupied by the remarkable 193rank.

\subsection{The Concept of Administrative and Financial Corruption}

Corruption is defined as the misuse of the public function for the private gain [17].

The United Nations defines it as the abuse of public authorities to achieve personal gains [18].

Administrative and financial corruption I also known as the moral degeneration of some public officials and administrative and financial corruption include bribery, fraud, fraud, tax evasion, fraud,...etc [19].

The manifestations of administrative and financial corruption [20].

Bribery: A person is given the benefit to carry out an illegal act.

Favoritism: the approval of the organizations [regions, regions or influential families] through their influence without entitlement.

Wasta: The intervention of another person with a status functional or political for the benefit of those who do not deserve the service or appointment or assignment of a contract, position or tender [21].

Extortion and fraud: For the purpose of obtaining money by hiding information, forging certificates or exploiting bad information against persons or companies.

Looting or embezzlement of public money: the use of the powers of the function for personal benefits.

Money laundering: the transfer of illegal funds to the funds to legal funds and the secrecy and possession of it so that it seems taken by legal ways.

Tax evasion and fraud: circumventing the payment of taxes by illegal methods.

Political corruption: the corruption of members of parliament and the use of the fortress to profit from political action or smuggling of imported goods.

Recycle funds of foreign aid to personal pockets.

Compensatory loans: Banks give unsecured loans to influential people and business leaders.

Allocation of land: It is taken in the form of gifts and donations without right.

The following table (2) refers to indicators for the Arab countries for the years $(2011,2013,2015)$ : 
Table 2. Indicators for the Arab countries for the years (2011, 2013, 2015).

\begin{tabular}{|c|c|c|c|c|c|c|c|c|c|c|}
\hline Country & & Qatar & UAE & Oman & Bahrain & Jordan & Tunisia & Kuwait & Morocco & Saudi Arabbia \\
\hline index result & & 7.2 & 6.8 & 4.8 & 5.1 & 4.5 & 3.8 & 4.6 & 3.4 & 4.4 \\
\hline \multirow{2}{*}{ Ranking 2011} & Arab & 1 & 2 & 4 & 3 & 6 & 8 & 5 & 9 & 7 \\
\hline & international & 22 & 28 & 50 & 46 & 56 & 73 & 54 & 80 & 57 \\
\hline Index result 2013 & & 6.8 & 6.9 & 4.6 & 4.8 & 4.5 & 4.1 & 4.3 & 3.7 & 4.6 \\
\hline \multirow{2}{*}{ Ranking 2013} & Arab & 2 & 1 & 4 & 3 & 6 & 8 & 7 & 9 & 5 \\
\hline & International & 28 & 26 & 61 & 57 & 66 & 77 & 69 & 91 & 63 \\
\hline \multirow{2}{*}{ Ranking 2015} & Arab & 1 & 2 & 7 & 5 & 3 & 8 & 6 & 11 & 4 \\
\hline & international & 22 & 23 & 60 & 50 & 45 & 76 & 55 & 88 & 48 \\
\hline
\end{tabular}

Table 2. Continued.

\begin{tabular}{|c|c|c|c|c|c|c|c|c|c|c|c|}
\hline Country & & Algeria & Djibouti & Lebanon & Egypt & Mauritania & Libya & Yemen & Syria & Sudan & Iraq \\
\hline index result & & 2.9 & 3 & 2.5 & 2.9 & 2.4 & 2 & 2.1 & 2.6 & 1.6 & 1.8 \\
\hline \multirow{2}{*}{ Ranking 2011} & Arab & 11 & 10 & 14 & 11 & 15 & 17 & 16 & 13 & 19 & 18 \\
\hline & international & 112 & 100 & 134 & 112 & 143 & 168 & 164 & 129 & 177 & 175 \\
\hline Index result 2013 & & 3.6 & 3.6 & 2.8 & 3.2 & 3 & 1.5 & 1.8 & 1.7 & 1.1 & 1.6 \\
\hline \multirow{2}{*}{ Ranking 2013} & Arab & 10 & 11 & 14 & 12 & 13 & 18 & 15 & 16 & 19 & 17 \\
\hline & International & 94 & 94 & 127 & 114 & 119 & 172 & 167 & 168 & 174 & 171 \\
\hline \multirow{2}{*}{ Ranking 2015} & Arab & 9 & 12 & 14 & 10 & 13 & 18 & 16 & 15 & 19 & 17 \\
\hline & international & 88 & 99 & 123 & 88 & 112 & 161 & 154 & 154 & 154 & 161 \\
\hline
\end{tabular}

\subsection{The Study Problems and Its Questions}

Countries face wide challenges in controlling administrative and financial corruption in their departments, institutions and ministries. The e-government is one of the most important ways in which many countries have provided the time and speed to provide various services to its citizens and to monitor its employees and to minimize administrative and financial corruption. It faces other challenges in determining the quantity and quality of information technology in its current form, which is used to achieve its various objectives, The problem of the research is to measure the impact of e-government in reducing the phenomenon of administrative and financial corruption. The research problem is based on the following questions:

\subsubsection{Question}

1. What is the reality of e-government and Jordanian levels of use?

2. What are the obstacles to the application and use of egovernment?

3. What are the causes of administrative and financial corruption in Jordan?

\subsubsection{Study Hypotheses}

Are there differences of statistical significance at the level of mean $9 \geq 0.05$ between the average scores of the sample of the obstacles to the use of electronic government depending on the variables:

1. Gender.

2. Study qualification.

3. Years of experience.

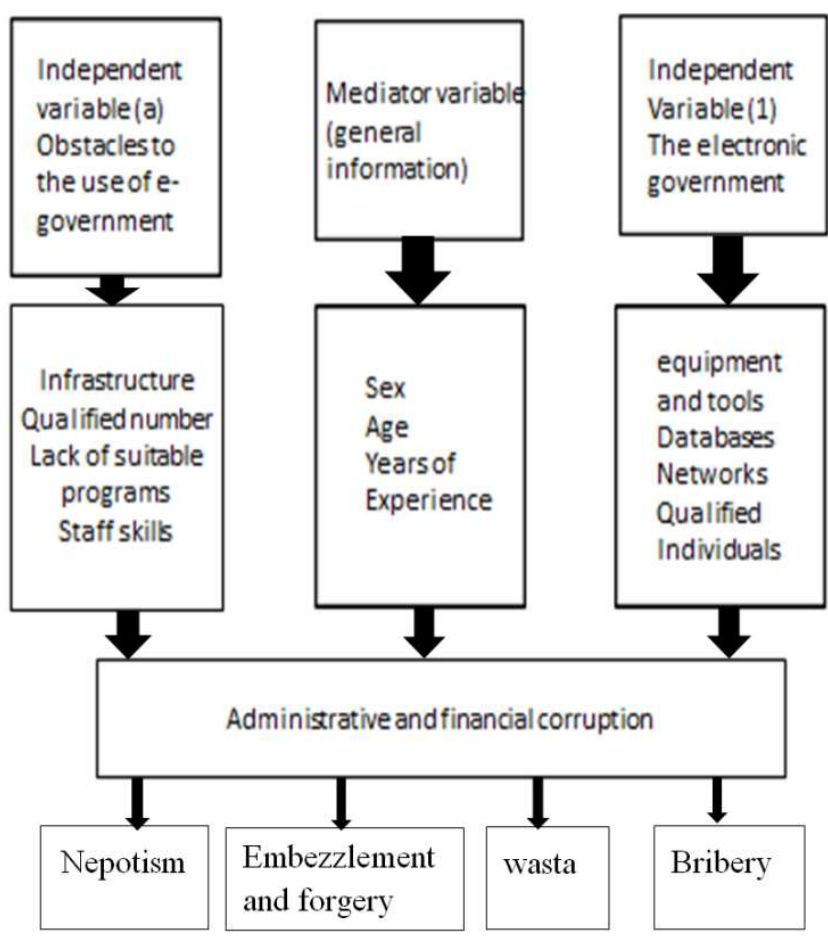

Source: Preparing the researcher for research purposes.

Figure 1. The default search form.

\subsection{Research Importance}

1. Spreading awareness of the importance of egovernment and the benefits of its application.

2. To raise awareness of the importance of knowing the causes of administrative and financial corruption in Jordanian state institutions. 
3. To enhance the regulatory aspect of e-government in combating administrative and financial corruption.

4. It is hoped that this study will be the nucleus of other studies and reference framework.

\subsection{Study Objectives}

The main objective of this study was to uncover the reality of the e-government in Jordan and the obstacles to its implementation and to explain the causes of administrative and financial corruption in it.

\subsection{The Limits of the Study}

The study is limited to the following limits:

Subject: Understanding the reality of electronic government in Jordan.

Institutional: Jordanian Ministry of Finance and its geographical location in Amman.

Human Resources: Employees of the Jordanian Ministry of Finance.

Temporal: This study was applied at the end of 2018 AD.

\subsection{Study Terms and Definitions}

E-Government: A Group of Uses of Information Technology, Telecommunications and External
Communication Networks and Their Linking to Internet Sites, Computer Systems and Software Needed by Government Agencies on a Hand and Citizens on the Other Hand. (22)

Administrative and Financial Corruption: Misuse of Office or Power for Personal Gains. (23)

\section{Society Study}

The study population consists of all 262 employees of the Jordanian Ministry of Finance at the end of 2018.

\subsection{The Study Sample}

The study sample consisted of 176 employees and their employees were selected in a relatively random class manner of employees in the ministry directors and heads of departments, different staff in the experience and ranks at a rate of $67 \%$ of the total staff in the ministry, change proportion had a good representative of the study community, And can be relied upon in completing the study procedures, and the following table 3 shows the distribution of the sample of the study on their variables gender, study qualifications, years of experience.

Table 3. Distribution of the sample of the study on the variables of the study.

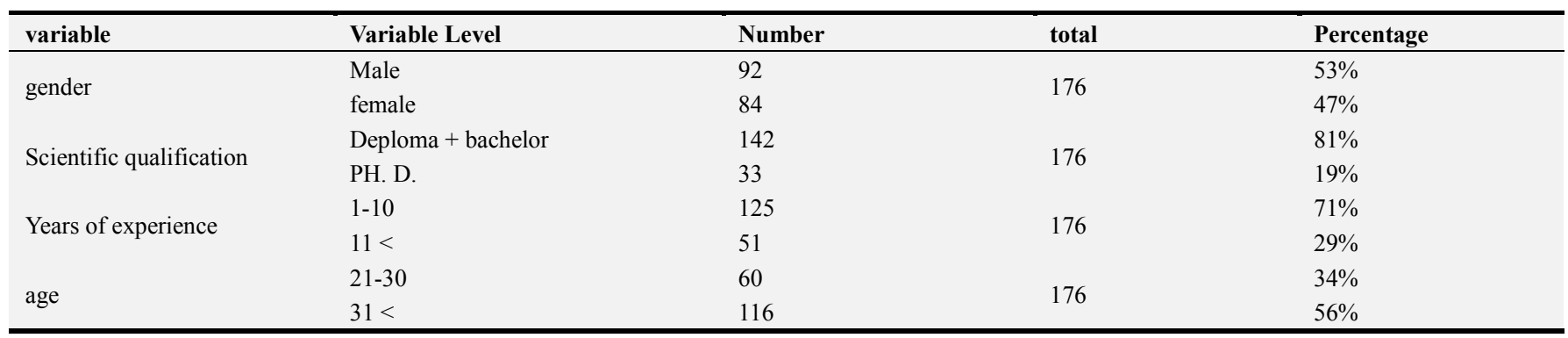

The percentage of males is $53 \%$ of the study sample while the percentage of females was $47 \%$ and the proportion of scientific qualifications accounted for the proportion of diploma and bachelor's was $81 \%$, And the graduate of high education $19 \%$. The years of experience for those who served between 1 year and 10 years was $71 \%$ and the percentage of those who served more than 10 years was $29 \%$ and The percentage of age groups from 20-30 years of age was 34\%, while the percentage of those aged over 31 years was $56 \%$ [24-25].

\subsection{Study Tool}

The researcher built the study tool and is a questionnaire to identify the obstacles and the reality of the e-government and the causes of administrative and financial corruption. The Ministry of Finance was chosen according to the following steps:

1. Review literature and studies related to this aspect previously.

2. Determining the areas of administration: the reality of the Jordanian e-government and obstacles to the implementation of the electronic government in Jordan and the causes of administrative and financial corruption.

3. Formulate study questions and a number of items under each area of management.

\subsubsection{Estimates Used in the Tool}

(5) I agree (4) Neutral (3) Strongly disagree (2) Disagree (1) Do not agree

\subsubsection{Tool Validation}

The tool was presented to experienced and competent arbitrators in the field of e-government, computer specialties, administrative information systems and scientific research methods to propose what they deemed appropriate, And to put notes on the items of the tool and in the light of the comments received was added some items and merge others and delete part of them and modify another part, The tool was formed after the final amendments of 27 questions distributed to three areas by the question of each field, First, 
the reality of the e - government (9) items and obstacles to the application of e-government (9) items and causes of administrative and financial corruption (9) items.

\subsubsection{Stability Tool Study}

To verify the stability of the study tool, it was applied to a random sample of 30 employees outside the actual sample and by extracting the stability coefficients according to the equation (Kronbach Alfa) results were as in Table 4.

Table 4. Extracting the stability coefficients.

\begin{tabular}{lll}
\hline Stability coefficient & Statement & field \\
\hline 0.85 & The reality of e-Government application in Jordan & First \\
0.83 & Obstacles to the application of e-government in Jordan & Second \\
0.81 & The causes of administrative and financial corruption in Jordan & third \\
\hline
\end{tabular}

The researcher considered the computed coefficients acceptable for the purposes of the current study.

\subsection{Statistical Processing}

The mean and percentages of the sample responses were used and tested with t. test, two independent samples were used to study the differences between the different study variables, The researcher has adopted three levels of analytical estimation of the items of the tool and is determined by the following percentages:

The percentage of $70 \%$ and more means the success of the implementation of e-government to a large extent in Jordan and offset by the arithmetic mean (3.5) and more.

The percentages of $50 \%$ to less than $70 \%$ mean the success of the implementation of the Jordanian e-government at an average level and corresponding to the mean (2.5) less than (3.5).
The percentage below $50 \%$ means the success of the Jordanian government is too small extent, and the average of the arithmetic average is less than (2.5). The previous estimates were adopted after the approval of the arbitrators on these ratios percentages and the corresponding arithmetic averages.

\section{Study Results and Discussion}

Results related to the answer to the first question and read:

What is the reality of the Jordanian e-Government application and its levels of use?

To answer this question, the arithmetical averages and percentages of the responses of the study sample were calculated and the results were recorded to the following table 5, which represents the reality of e-government in Jordan:

Table 5. Statistical averages and standard deviations of the field of e - government reality and availability.

\begin{tabular}{lllll}
\hline number & Item & Statistical Average & Standard deviation & Percentage \\
\hline 3 & E-Government keeps abreast of qualitative development in its management & 4.41 & 0.81 & 83.41 \\
2 & processes. & 4.01 & 0.8 & 80.32 \\
4 & E-government provides time and effort to the citizen. & 3.98 & 0.91 & 79.82 \\
7 & E-government provides lesser money and expenses to complete transactions. & 0.93 & 78.31 \\
9 & Employees in the ministry have a high degree of electronic knowledge. & 3.91 & 0.9 & 77.41 \\
1 & E-government provides security and confidentiality of transactions. & 3.89 & 0.91 & 77.21 \\
8 & E-government provides various software to meet business needs. & 3.84 & 0.83 & 77.1 \\
5 & Electronic governments use appropriate communication tools. & 3.8 & 0.82 & 76.7 \\
6 & Input control and outputs is used effectively. & 3.78 & 0.8 & 76.1 \\
& Government employees are subject to intensive and periodic training. & 3.71 & 0.9 & 80.1 \\
\hline
\end{tabular}

The table above shows that the paragraph (e-government keeping pace with qualitative development in its administrative processes) has obtained the highest arithmetic averages (4.41), (E-government employees are subject to intensive and periodic training) on the lowest average account, where it was equal to (3.71), This may be due to the fact that periodic training of government employees on equipment, software and equipment costs the treasury funds, Therefore, when such training is conducted, it is necessary to save the money of the country, Which is known to be dependent on foreign aid, as Jordan lacks natural resources from oil, gas and other minerals.

The e-government is keeping pace with the qualitative development of its administrative processes due to the government's keenness to follow the rapid developments in the world of electronic services and fast communication.

\section{Testing Hypotheses}

1. Statistical results show that confidence in the egovernment in Jordan is still weak due to the environment of the region closest to agriculture and Bedouin to modern civilization.

2. The least disabilities in the application of e-government was the young people that they had the opportunity to modernize the newly introduced technology in government works and that they benefited from training 
and conferences and attend seminars that increased their knowledge of e-government.

3. There are no statistically significant differences due to gender between the two parties in terms of egovernment applications due to the similar conditions of training, bonuses and salaries.

4. The general economic conditions and the low standard of living and wages were the main reason behind the spread of the phenomena of administrative and financial corruption that Jordan suffers from economic crises suffocating because of the circumstances of the region and the resort of millions of Syrians, Iraqis, Yemenis and the Libyans. Moreover, the region lacks the oil, gas and water resources.

\section{Results}

A survey of the sample of the study and review of the results of the statistical analysis revealed some important results:

First: the absence of government supervision, laws and penalties deterrent violators, which led to the persistence of some employees in the exploitation of the need of people, which led to the spread of financial and administrative corruption as well as some social diseases such as bribery and favoritism and the exploitation of the job of some staff, not all.

Second: The deterioration of the economic situation in Jordan because of the migration of millions of Syrians, Iraqis, Yemenis and Libyans who have fled the scourge of war in their country has increased the burden on the government and employees, which reduced the job opportunities and increased unemployment and poverty, leading to the spread of financial and administrative corruption among employees and citizens who seek to complete their transactions to follow the illegal methods to achieve this, including the provision of bribery to employees.

Third: The non-activation and follow-up of e-government programs effectively, in addition to the lack of qualified cadres of programmers, technicians and analysts to follow the management of e-government, leading to weakness in their application, especially in the control of the work of employees and auditors.

Fourth: the absence of electronic deterrent legislation for the violators of employees and citizens, which weakened the role of e-government and did not achieve the goal of its implementation.

Fifth: Opposition to the application of electronic government procedures and transactions by citizens and a large group of employees contributed to reducing the power of e-government and thus did not bear fruit well in the accounting of financial and administrative corruption and cracking down on offenders and deter them and eliminate these serious social diseases.

\section{Conclusion}

The study concluded that the implementation of e- government procedures in Jordan has not been successful One hundred percent because of the lack of conviction of citizens and modernity of their era on the one hand and on the other absence The deterrent powers to hold violators accountable and the lack of effective electronic censorship to prevent financial and administrative corruption.

And the absence of supporting programs to implement and implement e-government procedures.

The researcher believes that the success of the electronic government and based on the results of the study needs more time, In order to convince citizens and change their ideas about e-government. In addition to the adoption by the state of effective electronic control system and training of staff more and Creating a conviction of the importance of egovernment to employees and citizens and encouraging and rewarding good employees.

\section{References}

[1] Foreign Direct Investment between the determinants of globalization and the problematic of the Iraqi investment environment / Prof. Basem Jamil Khalaf, research published in the Journal of the College of Baghdad for Economic Sciences University / Special number of the College Conference (Baghdad, 2013).

[2] Islamic Economics Introduction and Methodology. Ashraf Mohammed Douabah (Cairo, 2010).

[3] Political Economy of Corruption / Munir Al-Hamash, Research published in the Arab Future Journal, 328, Center for Arab Unity Studies (Beirut, 2006).

[4] Analysis of the Forms and Methods of Financial and Administrative Corruption in Iraq / Ali Sukkar Abboud, published in Qadisiyah Journal of Administrative and Economic Sciences, Volume 1, 2010.

[5] Sustainable Development / Mohiuddin Al-Hamdani, PhD thesis, Egypt [Al-Azhar University, 2009].

[6] Criminal Policy in Saudi Arabia / Saad bin Abdullah Al-Arifi, Al-Rashed Library, 2 [Riyadh, 2012].

[7] Arab International Conference Against Corruption [Riyadh, $1424 \mathrm{H}]$.

[8] The role of the judiciary in the fight against corruption / Hassan Abu Naama, from the research of the Arab International Conference against Corruption [Riyadh, 2014].

[9] Supervisory role against corruption / Abdul Latif Mosleh, paper presented to the National Institute of Administrative Sciences [Yemen, 2017].

[10] Study of the situation of Iraq under occupation / Salem Tawfiq Al-Najafi, in the symposium on corruption and good governance in the Arab countries, Center for Arab Unity Studies (Beirut, 2014).

[11] Exchange rate of the Iraqi dinar, a hole swallows foreign exchange reserve / AD Abdul Hussein Mohammed Abbas AlAnbuge, research published on the website of the Iraqi economists Baghdad on 16/7/2015, the number of electronic link (Iraqi economists' AR). 
[12] The factors determining the growth of foreign investment / Awad bin Awad Salem, University House [Egypt, 2014].

[13] Administrative Corruption and the Future Society Mr. Ali Shattar, Alexandrina Library, [Alexandri, 2013].

[14] Administrative and financial corruption and its economic and social effects / Hashim Al-Shammari and Ithar Al-Fatali, Dar Al-Bazouri for Publishing and Distribution [Amman, 2011].

[15] Financial corruption, its causes, image and treatment / Dr. Hussein Hussein Shehata, published article on the page of the Islamic awareness magazine, No. 552, July [Kuwait, 2011].

[16] Corruption and Globalization Synchronization No twinning / Amer Al-Kubaisi, Modern University Office [Riyadh, 02015].

[17] Administrative Corruption The Conflict of Morals and Interests / Shragan Al-Rashidi, Journal of Administration, Issue 35: [Safar, 2014].

[18] Corruption and its Impacts on the Climate of Foreign Investment: A Paper Presented to the Corporate Governance Cycle to Reduce Corruption [Algeria, 2014].

[19] Financial and administrative corruption in Iraq and ways of dealing with it. Mohammed Ghali Rahi, Research published in the Journal of Kufa, No. 1 [Faculty of Law, 2009].
[20] Corruption: A study of causes and economic effects, Kamal Amin Al-Wasal, World of Thought Magazine, Volume 38, National Council for Culture, Arts and Letters [Kuwait, 2009], p. 329.

[21] The corruption of its roots and its bitter fruits in Iraq / Hasan Latif al-Zubaidi and Atef Lafi al-Saadoun, published in the Journal of Economic Studies, No. 18, Beit al-Hikma (Baghdad, 2016).

[22] How to protect our staff against administrative corruption/ Ibtisam Abdel Rahman Al Halawani, the third Arab Conference in the administration (Beirut, 2012).

[23] The Effect of E-Government on Monitoring Financial Violations of the Jordanian Ministries and Ways of Combating Financial Corruption in them. Unpublished Master Thesis, University of Jordan Amman, Jordan 2018.

[24] E-government after the US occupation of Iraq and its role in the fight against corruption Financial institutions. Unpublished Master Thesis, Yarmouk University, Irbid, Jordan, 2017.

[25] The role of e-government in improving public services and combating financial corruption/ Unpublished Master Thesis, University of Bouira. Algeria. 